\title{
地下水へ注入された空気による水質回復の効果について
}

\author{
江種伸之*・平田健正*・福浦 清**・松下 孝**

\section{Effect of Air Migration on Recovery of Contaminant Concentration in Groundwater}

\author{
Nobuyuki EGUSA*, Tatemasa HIRATA*, \\ Kiyoshi FUKUURA** and Takashi MATSUSHITA**
}

\begin{abstract}
The air sparging coupled with the soil vapor extraction as the physical remediation technologies has been applied to a site contaminated with volatile substances like tetrachloroethylene. The air sparging technology facilitates the contaminant volatilization with air injected into saturated zone and the soil vapor extraction technology extracts the contaminant in soil gas and injected air. Therefore, in order to implement these technologies, it is indispensable to understand the mechanism of air migration injected in groundwater and the change of groundwater concentration. In this paper, we presented the results of full scale field experiment implemented to estimate the recovery of water quality by air injected in groundwater. The summery was follows. It was clarified that injected air spread sufficiently in an experimental site when the pulsed operation for air injection was carried out. The concentration in injected air, which was calculated by the observed data like extracted gas concentration, showed the possibility that there would be the denser-than-water non-aqueous phase liquid in an aquifer. And also, it has been removed with the substances dissolved in groundwater by air injection.
\end{abstract}

Key Words: groundwater contamination, volatile substances, remediation technology, air sparging, full-scale field experiment

* 和歌山大学 システム工学部 環境システム学科(

e-mail: )

**前澤工業株式会社 土壤環境部 


\section{要 旨}

テトラクロロエチレンなどの揮発性物質によって污染された地下環境の修復技術とし て、その揮発性に注目したエアースパージング技術が適用されることが多くなってきてい る。エアースパージング技術は地下水中に空気を吹き込み、地下水の流れを攪拌すること で溶解している物質を揮発させ、不飽和帯でガスとして除去する。すなわち、この方法を 適用するためには、注入空気の動きや地下水中の物質濃度変化などを明らかにする必要が ある。本稿では、実際に揮発性物質で地下水が污染された現場にエアースパージング技術 を適用し、空気の注入によって地下水水質が回復していく様子を検討した。その結果、空 気注入を断続的に行う間欠運転によって、注入空気が実験对象となる地下水帯を十分拡が ることが明らかになった。また、抽出ガス濃度などの観測データから注入空気に揮発した ガス濃度を算定することで、地下水中に溶解している物質の揮発だけでなく、現地帯水層 中に原液が存在している。その原液が注入空気へ揮発することで地下環境中から除去され つつある状況が推察された。

キーワード：地下水污染、揮発性物質、浄化対策技術、エアースパージング技術、実スケー ル野外実験

\section{1. はじめに}

地下水・土壤污染の浄化対策技術は、地下水や 土壤環境から污染物質を除去し、無害化するもの であるが、大きくは(1)污染物質の拡散防止技術と (2)污染物質の分解・除去技術に分けられる。その 中で有機塩素化合物などの揮発性物質による地下 水・土壤污染に対しては、最近では特にその揮発 性に注目した土壤ガス吸引技術やエアースパージ ング技術が多くの現場で適用されている(例え ば、平田ほか、1996)。土堙ガス吸引技術は、不 飽和帯に負圧をかけて土壤ガスの吸引を行い、ガ ス態の物質を除去する。この方法では地下水の揚 水を同時に行う場合が多く(二重抽出法)、地下水 中に溶解している物質も除去できる。ただし、揚 水した地下水を地上でばっ気処理する必要があ り、処理水の処分方法が問題になる。一方、エアー スパージング技術は、通常は土壤ガス吸引技術と 併用されるが、地下水中に空気を吹き込み、地下 水の流れを攪汼することで溶解している物質を注 入空気に揮発させ、不飽和帯でガスとして除去す る。この方法は二重抽出法とは異なり、(1)污染さ
れた地下水の処理が不要になる、(2)土壤ガス吸引 技術と同様な地上設備で設置が簡単、(3)費用が安 くなるなどの利点がある。しかし、空気を吹き込 むことで地下水が乱されるため、地下水や土壤ガ ス中の物質の回収量に影響が生じる。また、污染 物質を周辺へ散逸させる危険性もある。すなわち、 注入空気の移動特性や空気通過による物質濃度変 化の様子を明らかにして扔くことが、エアースパー ジング技術の効果を上げるためには重要である。

Ji et al.(1993)は室内実験を行い、自然の飽和 土壤中に注入された空気は気泡ではなく、細い流 路を形成して流れることを示した。Unger et al. (1995a，1995b）は污染された地下環境が回復する 様子を数值シミュレーションによって検討し、エ アースパージング技術の有効性を示した。 Lundgard and LaBrecue(1995) は揮発性物質で污 染された現地で予備実験を行い、electrical resistance tomography (ERT)が地下水中に注入された 空気の移動をよく表す指標として有効であること を示した。また日本においては、笠水上ほか (1995，1997)がエアースパージング技術を現地に 適用した結果を報告している。 
以上のように、エアースパージング技術に関す る研究例が数々報告されている。しかし、注入空 気の動きや地下水中の物質濃度变化について検討 を行ったものは少なく、メカニズムが十分解明さ れているとは言えないようである。そこで、著者 ら (1998) は揮発性物質によって地下水が污染され た現場で短期間の予備実験を行い、エアースパー ジング技術を適用した場合の注入空気の移動特性 や物質輸送過程の解明を行ってきた。本稿では、 予備実験に続いて実施された長期実験結果をもと に、地下水・土壤環境の回復状況 (帯水層の浄化) について検討した結果を報告する。

\section{2. 現地概要}

対象となったのは化学工場で、現在は跡地に なっている。現地の地質状況は、地表面から G.L. $-4 \mathrm{~m}$ までが表土とローム層、G.L. $-5 \mathrm{~m}$ 過ぎまでが 凝灰質粘土層、その下は砂質粘土、砂質シルト、 シルト質細砂と移行し、G.L.-8m 過ぎから砂層と なっている。凝灰質粘土層の上には宙水が存在し ており、その下は不飽和帯を挟んで G.L. $-11 \mathrm{~m}$ 付 近から地下水帯を形成している。この地下水帯は 深度 G.L.-30m 以下まで続いているが、G.L.-18m 付近に固結した砂層があり、ここを境として地下 水帯上部と下部に分かれる。現場周辺での地下水 流れの方向は北東から南西であり、流速は $30 \mathrm{~m}$ year-1程度である。

宙水帯と地下水帯に挟まれた不飽和帯で透気試 験を行ったところ、透気係数はほほ全域で $10^{-4} \mathrm{~cm}$ $\sec ^{-1}$ のオーダーで、実験対象領域内の地質に水平 方向の異方性は見られなかった。ここで、透気試 験は土壤ガス吸引期間中の周辺土壤ガス圧力の変 化量から透気係数を算定する方法で行った(例え ば、長藤ほか、1998)。不飽和帯は上部が宙水帯 で地上大気と遮断されているため、土壤ガス抽出 によって $40 \mathrm{~m}$ 以上離れた観測井でも土塞ガス圧力 が低下していた。したがって、土壤ガス抽出の影 響はかなり広範囲に及んでいると思われる。また、 地下水帯上部のボーリングコアサンプルに難透水 性の土壤は見られなかった。

土壤中含有量の分析結果から、地下環境中には トルエン、テトラクロロエチレンの 2 物質が地下
水帯に多く存在していることが判明した。また、 地下水中濃度を測定すると、地下水面直下の G.L. $-12 \mathrm{~m}$ 付近で高く、深度とともに低下する傾向を 示した。そこで、本現場では地下水帯の浄化を目的 にエアースパージング技術を適用することにした。

現地では、まず注入空気の移動特性や影響半径、 そして空気注入による物質濃度変化の様子など、 本格的対策の計画・実施に必要な情報を得るため の予備実験を行った(江種ほか、1998)。その結果、 地下水中に注入された空気は鉛直上方から斜め上 方に向かって比較的狭い範囲に拡がっていること

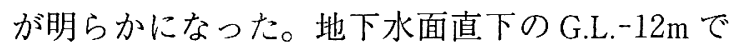
は、注入井からの水平距離が $4 \mathrm{~m}$ の観測井でも注 入空気の影響で濃度が低下していた。しかし、G. L. $-14.5 \mathrm{~m}$ 㧍よび G.L. $-17 \mathrm{~m}$ 付近では注入井から水 平方向に $4 \mathrm{~m}$ 離れると濃度が低下して扔らず、注 入空気が通過していても、その量は濃度を低下さ せるほど十分なものではなかった。

\section{3. 実スケール野外実験の概要}

\section{1 井戸配置}

現地での抽出井、注入井、および観測井の平面 配置を Fig.1に示している。実験対象領域のほぼ 中心部に注入井 $(\mathrm{Sd} 1)$ と抽出井 $(\mathrm{Vcl})$ を 1 本ず つ、そこを起点として互いに120度開いた 3 本の 直線上に注入井と抽出井をそれぞれ 1 本ずつ設置 した $(\mathrm{Sd} 2, \mathrm{Sd} 3, \mathrm{Sd} 4, \mathrm{Vc} 3, \mathrm{Vc5}, \mathrm{Vc} 7)$ 。この 3 本の直線 は地下水流れの下流方向から時計回りに60度、 180度、300度開いている。起点から注入井までの 距離は $6 \mathrm{~m}$ 、抽出井までの距離は $15 \mathrm{~m}$ であり、実 験対象領域外にガス態の物質が散逸しないように 注入井の外側を抽出井が囲む配置にした。注入井 のうち Sd1は予備実験のみで使用し、今回の実験 では $\mathrm{Sd} 2, \mathrm{Sd} 3, \mathrm{Sd} 4$ の 3 本を使用した。抽出井は上 記の 4 本すべてを使用した。

地下水観測井は、上記の 3 直線上および地下水 流れの下流方向に12点設置した。12点のうちの 2 点 $(\mathrm{Md} 6, \mathrm{Md} 9)$ は梁度 G.L.-14.5m のみ、他の10点 は G.L. $-12 \mathrm{~m},-14.5 \mathrm{~m}$ および- $17 \mathrm{~m}$ の深度に井戸を 設けた。起点からの距離は最大 $20 \mathrm{~m}$ で、最寄りの 注入井からの距離は最大 $14 \mathrm{~m}$ となっている。この ような配置にしたのは、予備実験時には注入井か 


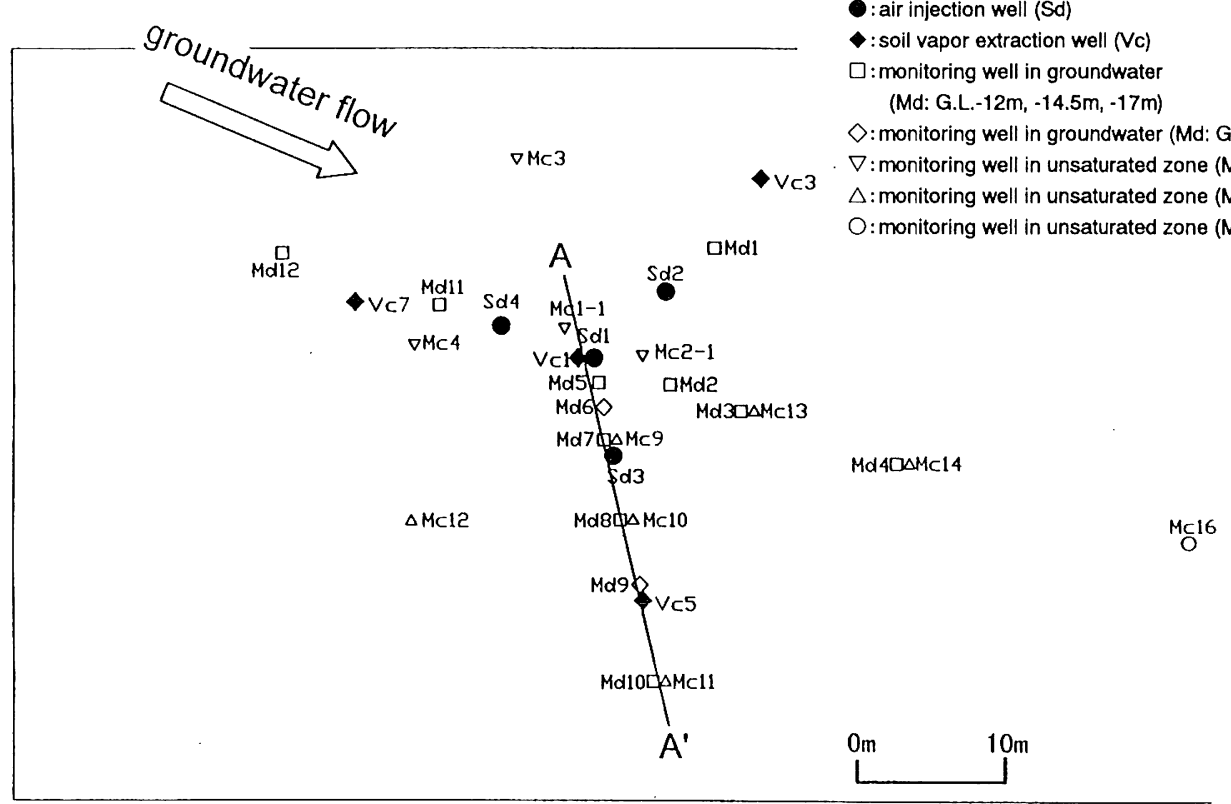

Fig. 1 Locations of extraction wells, injection wells and monitoring wells.

ら水平距離で $14 \mathrm{~m}$ 離れると注入空気の流れが観測 されなかったためである。不飽和帯観測井は、地 下水流れの下流方向から見て0度と60度の直線上 に重点的に、起点から最大約 $80 \mathrm{~m}$ の距離まで合計 13点設置した。ただ、遠方の 2 つの観測井 Mc17、Mc18は Fig.1には収まっていない。

\section{2 井戸構造}

注入井は深度 G.L. $-17.2 \mathrm{~m}$ で、内径 $25 \mathrm{~mm}$ のスク リーンを G.L.-16.7m〜17.2m 地点に設置した。抽 出井は深度 G.L.-11m で、内径 $140 \mathrm{~mm}$ のスクリー ンを G.L.-7m〜 11m 地点の不飽和帯に設置した。 地下水観測井は G.L. $-12 \mathrm{~m},-14.5 \mathrm{~m},-17 \mathrm{~m}$ の 3 種類 の深さで、内径 $13 \mathrm{~mm}$ のスクリーンを $0.5 \mathrm{~m}$ の厚さ で各井戸底に設置した。不飽和带観測井は深度 $\mathrm{G}$. L. $-9 \mathrm{~m}$ を基本としたが、一部- $8 \mathrm{~m}$ や- $10 \mathrm{~m} の も の ~$ もある (G.L. $-8 \mathrm{~m}$ : Mc1-1,Mc2-1,Mc3,Mc4、G.L. $-10 \mathrm{~m}: \mathrm{Mc} 16)$ 。スクリーンは内径 $10 \mathrm{~mm}$ 、厚さ0. $2 \mathrm{~m}$ のものを各井戸底に設置した。Fig.1中の A-A' ラインに沿った断面における井戸構造の概略図を Fig.2に示している。

\section{3 運転方法}

今回の実スケール野外実験では、不飽和帯でガ ス抽出を行いながら地下水中に空気を注入し、運 転の経過に伴う地下水および土壤ガス中の物質濃 度変化を長期的に観測した。運転はまず土潩ガス 抽出のみ開始した。空気注入は尒備実験等のため に短時間行っていたが、本格的な運転は土塞ガス 抽出を始めてから約120日後に開始し、本稿では この時を起点とした経過日数を使って時間を表 す。空気注入は 3 本の井戸 $(\mathrm{Sd} 2, \mathrm{Sd} 3, \mathrm{Sd} 4)$ のうち 1 本ずつ順番に120 $\mathrm{Lmin}^{-1}$ の流量で 1 時間動か し、その間他の 2 本は休止させる間欠運転で行っ

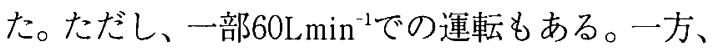
土壤ガス抽出は井戸 1 本当たり $120 \mathrm{Lmin}^{-1}$ の流量 で 4 本同時 $(\mathrm{Vc} 1, \mathrm{Vc} 3, \mathrm{Vc} 5, \mathrm{Vc7})$ に連続運転で行っ た。注入運転に関しては、問欠運転を $4 \sim 6$ 週間 続けた後に 1 週間の停止期間を設けた。これは注 入運転停止中に土壤ガスおよび地下水のサンプリ ングを行うためである。ただし、サンプリング中 も抽出運転は継続した。 


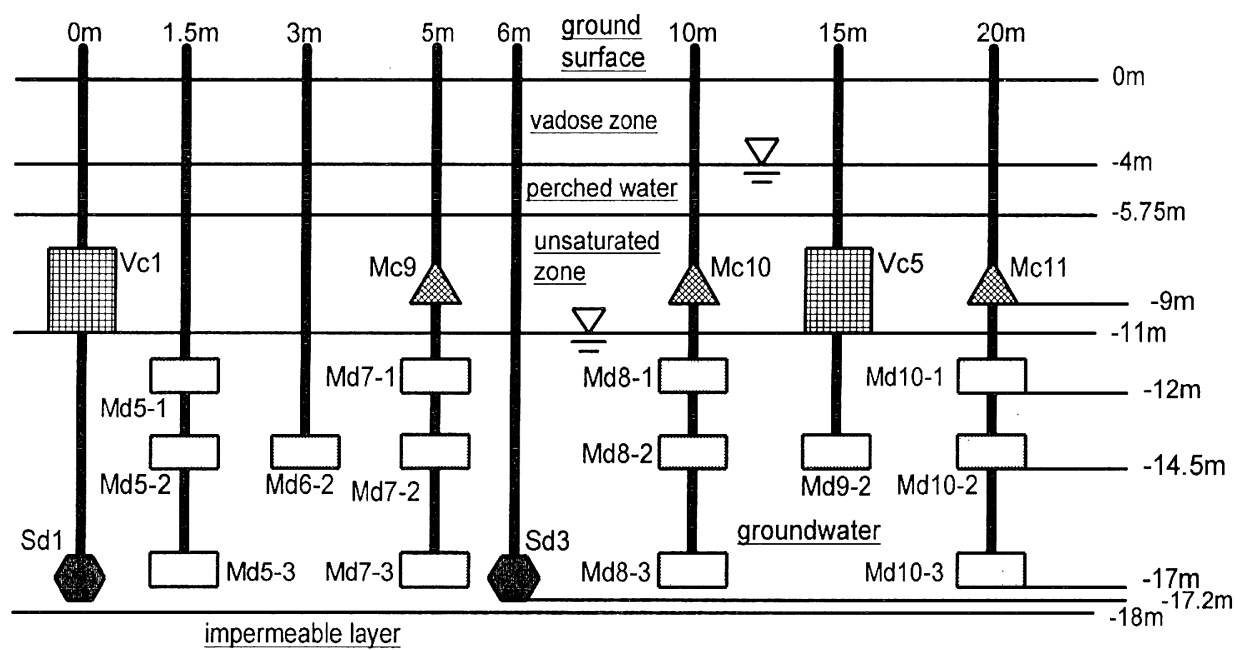

:soil vapor extraction well(Vc)

:air injection well(Sd)

:monitoring well in groundwater(Md)

:monitoring well in unsaturated zone(Mc)

Fig. 2 Locations of injection wells, extraction wells and monitoring wells along $A-A^{\prime}$ cross-section in Fig.1.

\section{4 観測項目}

\subsection{1 地下水中濃度}

1 回目の観測は注入運転開始の約20日前に行 い、105日後までは月 1 回、その後約225日後まで は 2 カ月に 1 回の頻度で観測した。前節でも述べ たが、地下水のサンプリングは注入運転を停止し てから 1 週間以内 $(3 \sim 7$ 日後)に行った。深度 $\mathrm{G}$. L. $-14.5 \mathrm{~m}$ と $-17 \mathrm{~m}$ の観測井ではポンプ (Solinst 社 製WaTerra Pump)を用い、ポリエチレンチュー ブを通してサンプリングした。深度 G.L.-12mの 観測井については、ポンプを使用できなかったた めベーラーを用いた。なお、井戸管内に滞留して いる地下水を分析しないように、井戸容積の 3 倍 以上排水した後にサンプリングした。濃度の定量 はポータブル GC-PID 装置 (HNU 社製)を用い、 標準データの取得はへッドスペース法により測定 日毎に 1 回以上行った。

\section{4 .2 ガス濃度}

抽出ガス濃度は、注入運転開始から約115日後 までは 1 週間毎に、その後は約225日後まで 2 一 4 週間の間隔で観測した。一方、土壤ガス濃度は、 地下水中濃度と同様に注入運転開始の約 20 日前に
1 回目の観測を行い、105日後までは月 1 回、そ の後約225日後までは 2 カ月に 1 回の頻度で観測 した。土壤ガスのサンプリングは地下水のサンプ リングと同様に注入運転を停止してから 1 週間以 内 ( $3 \sim 7$ 日後)に行った。抽出および土壌ガスの サンプリングは、密閉容器に入れたテドラーバッ グをナイロンチューブで抽出または観測井と接続 し、密閉容器内の空気を真空ポンプで排出するこ とでテドラーバッグ内に土壤ガスを取り込む方法 を採った。なお、井戸管内に滞留しているガスを 分析しないように、井戸容積の 5 倍以上の排気を 行った後にサンプリングした。濃度の定量には地 下水中濃度と同様にポータブル GC-PID 装置 (HNU 社製)を用い、標準データの取得はヘッド スペース法により測定日毎に 1 回以上行った。

\section{4. 結果と考察}

\section{1 注入空気の影響範囲}

Fig.3に地下水観測井Md7およびMd8における 地下水中濃度の経時変化を示している。G.L. $-12 \mathrm{~m}$ 地点で70日後以降の值がなくなっているが、これ 
は地下水の季節変動によって水位が低下し、地下 水がサンプリングできなくなったためである。予 備実験中の注入井 $S d 3$ 用いた運転 (-75日後)で は、観測井 Md7が注入井から水平距離で $1.5 \mathrm{~m} \mathrm{~L}$ か離れていないため、この近辺を通過する空気量 は他の観測井よりも多くなる。すなわち、注入空 気への揮発が促進されることになり、その影響で 濃度が大きく低下している。一方、Sd3から水平 距離で $4 \mathrm{~m}$ 離れた観測井 Md8では、一番上方の
Md8-1のみで濃度が低下する。G.L.-14.5m から G. L. $-17 \mathrm{~m}$ (観測井 Md8-2から-3) 近辺には十分な量 の空気が流れていないことがマウンディング試験 からわかっており、このことが濃度が低下しない 原因と考えられる(江種ほか、1998)。マウンディ ング試験とは、空気注入によって変化する地下水 位を観測し、水位上昇の程度から注入空気の影響 範囲を調べる予備試験である。

空気注入の影響があった観測井でも、予備実験
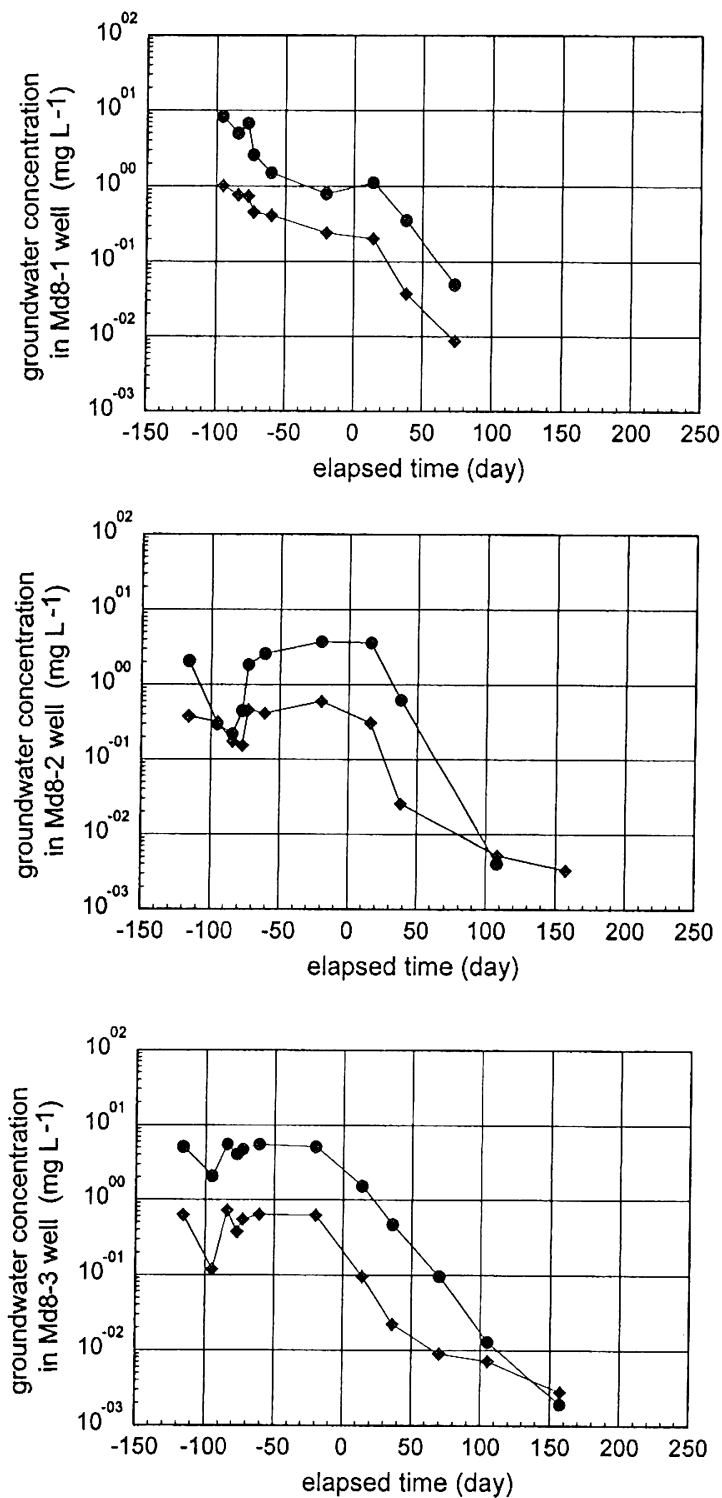

Fig. 3 Time varied change of groundwater concentrations in Md7 and Md8 wells.

$\checkmark$ : toluene, $\downarrow$ : tetrachloroethylene. 
終了後には濃度が回復している。しかし、長期実 験を開始すると Md7の 3 つの観測井では速やか に濃度が低下し始める。一方、観測井 Md8では、 予備実験で影響のあった Md8-1だけでなく、 Md8-2と-3でも濃度の低下が見られる。この現象 は、誌面には載せていないが、最寄りの注入井か らの水平距離が $4 \mathrm{~m}$ の観測井 $\mathrm{Md} 1 、 \mathrm{Md} 11$ でも確 認できた。すなわち、注入井から水平距離で $4 \mathrm{~m}$ 離れた地点では、長期運転時には地下水面近傍だ
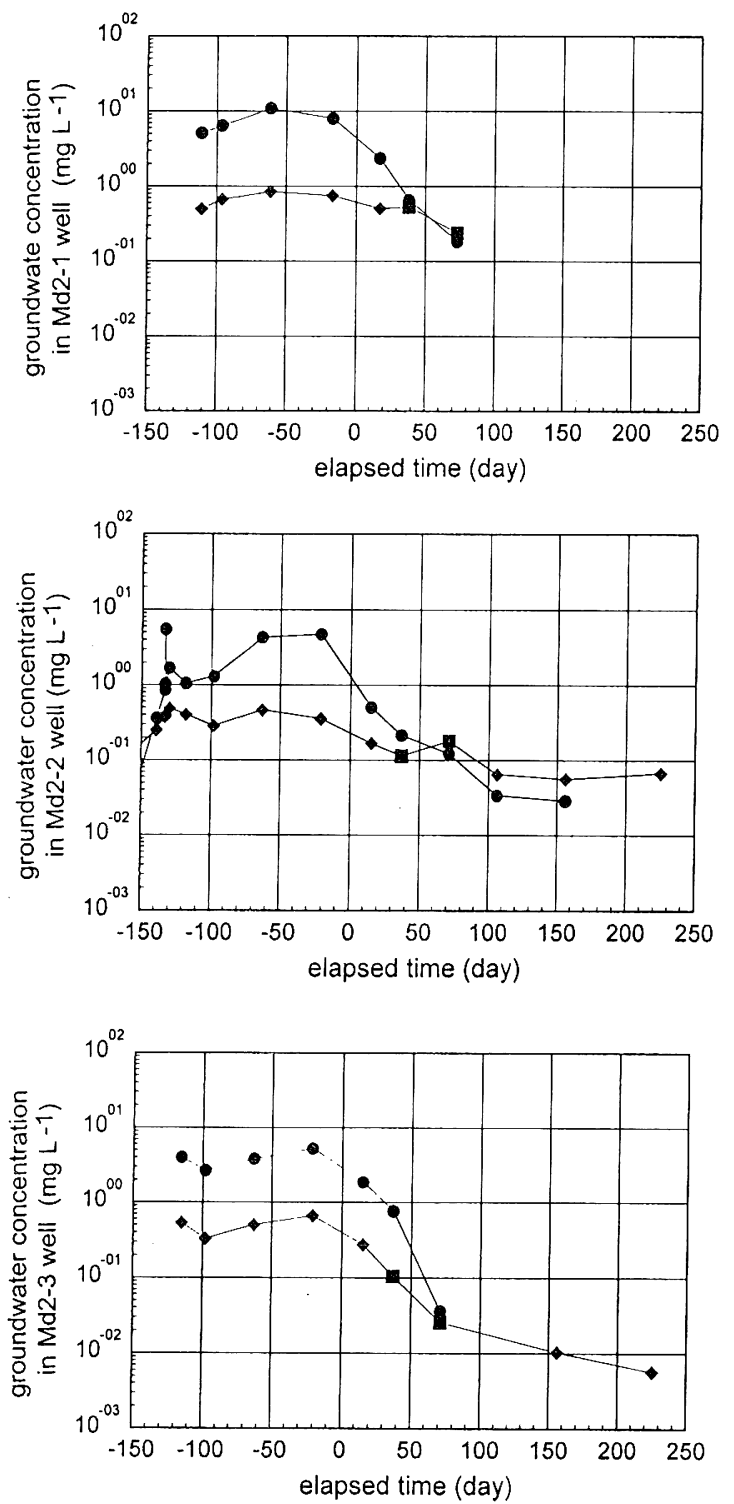

けでなく、地下水面下の深い場所 (G.L.-14m およ び G.L.-17.5m) でも注入空気の影響が現れている。

Fig.4に地下水観測井 Md2およびMd3における 地下水中濃度の経時変化を示している。注入井 $\mathrm{Sd} 2$ および $\mathrm{Sd} 3$ から水平距離で $5.5 \mathrm{~m}$ 離れた $\mathrm{Md} 2 て ゙$ は、空気注入を開始するとテトラクロロエチレン、 トルエンともに濃度が低下し始めており、この地 点にも注入空気の影響が現れている。一方、 $\mathrm{Sd} 2$ および Sd3から水平距離で10m 離れた観測井 Md3
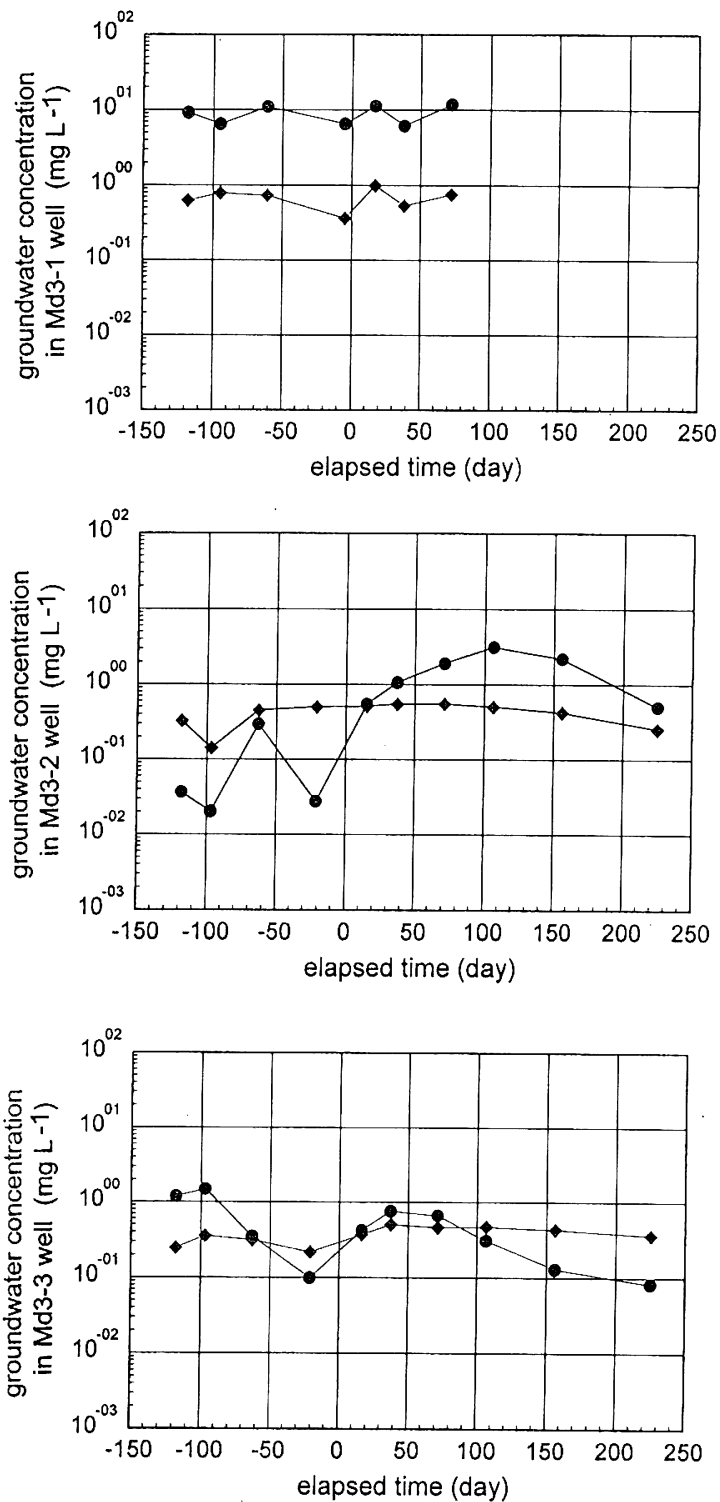

Fig. 4 Time varied change of groundwater concentrations in Md2 and Md3 wells. 
では、テトラクロロエチレン濃度の変化が非常に 小さく、注入井から $10 \mathrm{~m}$ 離れると注入空気の影響 はほとんど及んでいない。ただし、Md3-2では注 入運転開始とともにトルエン濃度が上昇してい る。100日後以降は低下しているので、はっきり したことはわからないが、空気注入によって地下 水が乱された影響かもしれない。同じような現象 がMd10-2でも観測されており、今後の濃度変化 に注意するとともに、室内実験や数值シミュレー ションなどによって、地下水の攪找やそれにとも なう物質の動きなどを調べることが必要だろう。

長期実験では予備実験中には注入空気の影響が 見られなかった観測井Md8-2,-3、およびMd2-1、 -2、-3でも濃度の低下が確認できた。すなわち、 水平距離で $5.5 \mathrm{~m}$ 離れた観測井の G.L. $-14.5 \mathrm{~m}$ 抢よ び- $17 \mathrm{~m}$ 付近にまで注入空気が拡がっていること になる。一方、地下水面直下の G.L.- $12 \mathrm{~m}$ では注 入空気の拡がりに予備実験との差がなく、影響範 囲は共に $5 \sim 6 \mathrm{~m}$ 程度である。このように、地下 水面近傍では予備実験との差が見られないもの の、地下水面下の深い場所では注入空気の影響範 囲が拡がっている。長期実験に扔ける注入空気の 影響範囲の概略を Fig.5に示す。長期実験では空 気の注入を間欠運転で行っているが、これは注入 空気の流れが定常になるのを防ぐためである。地 下水中の物質の揮発は空気流路近傍でしか生じな いため、空気の流れが定常になると濃度の低下す る領域が限定され、地下水水質の回復が進まない。 したがって、今回の実験で間欠運転を行ったのは、 注入空気の流れを定常にすることなく絶えず変化 させ、注入空気の影響を広範囲に伝えるためであ る。実際に地下水面下の深い場所では注入空気の 影響範囲が拡がって抢り、その目標は達成されて いる。

\section{2 空気注入によるガス濃度変化}

Fig.6には抽出井 Vc1 とその周辺に位置する不飽 和帯観測井 Mc1-1、Mc2-1におけるガス濃度の経 時変化を示している。抽出井 V $\mathrm{cl}$ では、テトラク ロロエチレン、トルエンの両物質とも時間が経過 寸るにつれて濃度が低下している。ただし、注入 開始から約70日後など、土壤ガス㧍よび地下水サ ンプリングのために空気注入を停止している期間

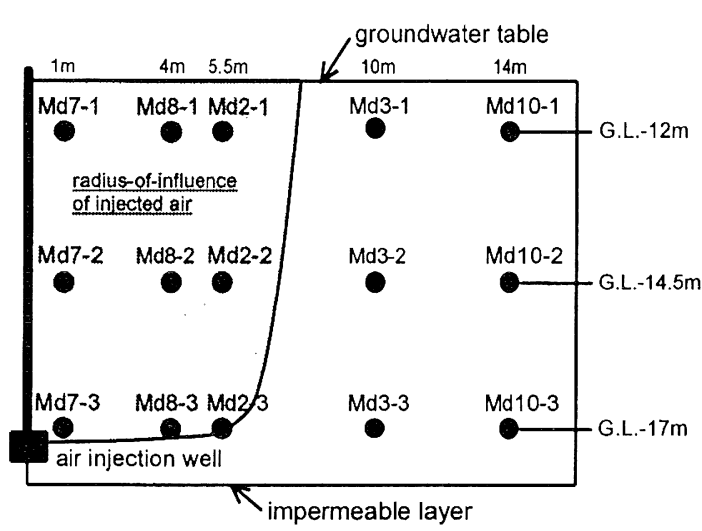

Fig. 5 Schematic illustration of the radius-ofinfluence for air injection during long term experiment.

には濃度が回復する。観測井 Mc1-1ではテトラク ロロエチレン、トルエン濃度が抽出ガス濃度と同 じような傾向で低下している。また、Mc2-1でも テトラクロロエチレンは抽出ガスとほほ同じ傾向 である。ただし、トルエン濃度だけは時間ととも に増加して扔り、抽出ガス濃度の動きと一致しな い。テトラクロロエチレン濃度に関して Vclと Mc2-1を比べた場合、抽出ガス濃度は空気注入期 間中は土壤ガス濃度よりも低く、注入停止期間中 は土壤ガス濃度とほぼ同じレ心゙ルにまで回復して いる。不飽和帯に達した注入空気は周辺土壤ガス と共に抽出井から回収されて抢り、空気注入期間 中の抽出ガス濃度は土壤ガス濃度と注入空気に揮 発したガス濃度の平均值になる (Fig.7a)。一方、 停止期間中は土壤ガスしか回収されないため、周 辺土䁃ガス濃度の平均值になる (Fig.7b)。土㙵ガ ス濃度に関しては注入停止期間中に測定している ため、その值に注入空気の影響は表れていない。 したがって、Vclに扔いて注入期間中に抽出ガス 濃度が低下し、注入を停止すると周辺土壤ガス濃 度と同じレベルに回復する現象は、注入空気に揮 発したガス濃度が周辺土塞ガス濃度よりも低いこ とを示している。紙面には載せていないが、抽出 井 Vc5と Vc7でも Vc1と同じ現象が見られた。た だし、設置位置の関係から最も近い注入井 1 本か らの空気しか回収しないため、3本の注入井に囲 まれているVc1ほと顕著な変化は出ていない。一 方、トルエン濃度に関しては、テトラクロロエチ レンのように空気注入による影響が特に見られな 
かった。また、Mc2-1のトルエン濃度の増加は、 今回の観測ではその原因を解明することができな かった。

Fig.8には抽出井 Vc3におけるガス濃度の経時変 化を示している。抽出井 Vc3では、他の抽出井と は異なり、空気注入停止期間中に両物質の濃度が 低下する傾向にある。Vc3周辺には観測井がない のではっきりしたことは言えないが、注入空気に
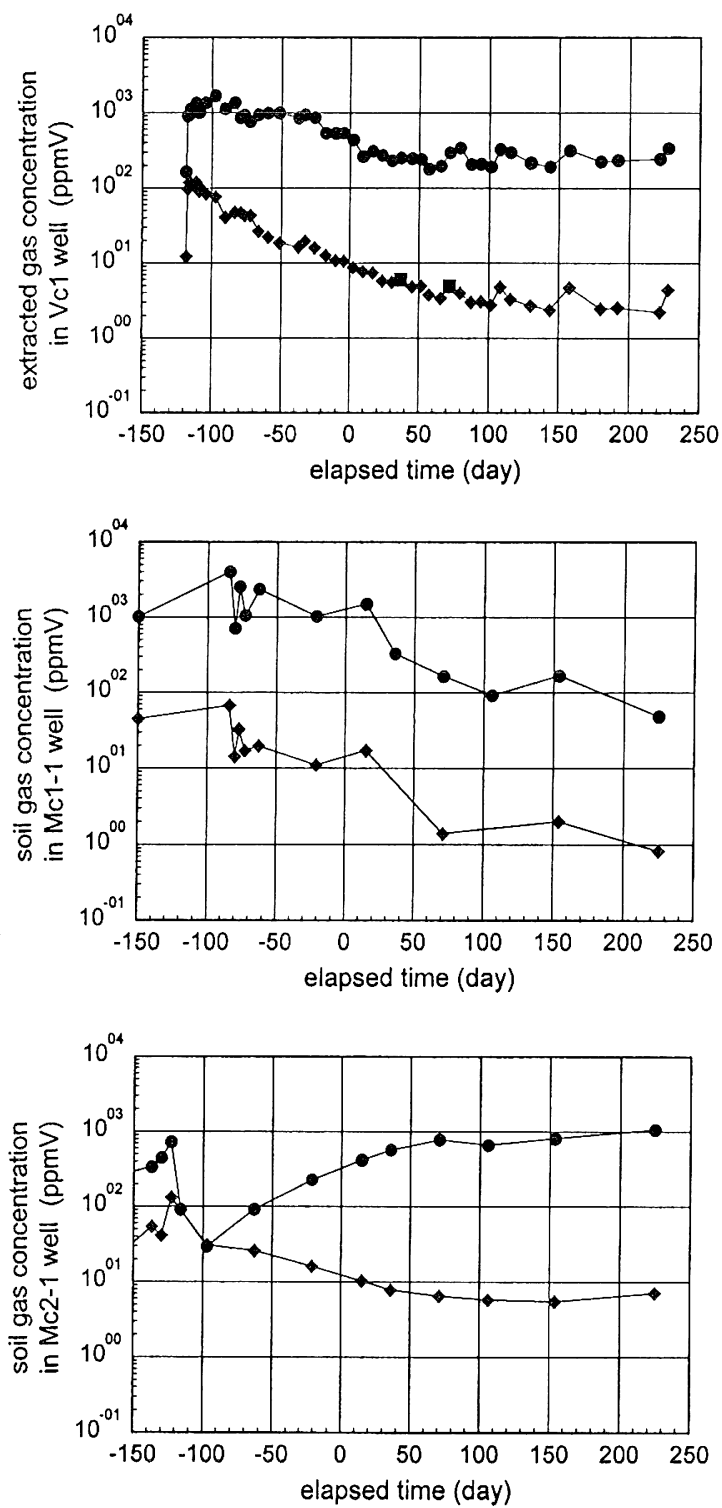

Fig. 6 Time varied change of gas concentrations in extraction well: $\mathrm{Vc1}$, monitoring wells:Md7 and Md8 wells.

: toluene, : tetrachloroethylene.
揮発したガス濃度が周辺土壤ガス濃度よりも高い ことを示している可能性が強い。

以上のことから、注入空気に揮発したガス濃度 の平均值は注入期間中に扮ける Vc3の抽出ガス濃 度よりも高く、Vc1よりも低いと予想される。

\section{3 注入空気に揮発したガス濃度}

空気注入期間中、抽出井からは土潩ガスと注入 空気が回収されており、抽出ガス濃度は土壤ガス と注入空気の平均值になる。一方、停止期間中に は土壤ガスしか回収されないため、周辺土塞ガス 濃度の平均値になる。したがって、注入期間中に Vc1の抽出ガス濃度が周辺土塞ガス濃度よりも低 くなる現象は、注入空気に揮発したガス濃度が周 辺土壤ガス濃度よりも低いことを示している。

そこで、この現象を利用して抽出井 Vc1から回 収される注入空気に揮発したテトラクロロエチレ ンガス濃度を算定してみる。今回のように長期的 な観測によって得られるデー夕は、対象領域内の 平均的な值を示しているので、計算にあたっては 以下の仮定が成り立っているものとする。なお、

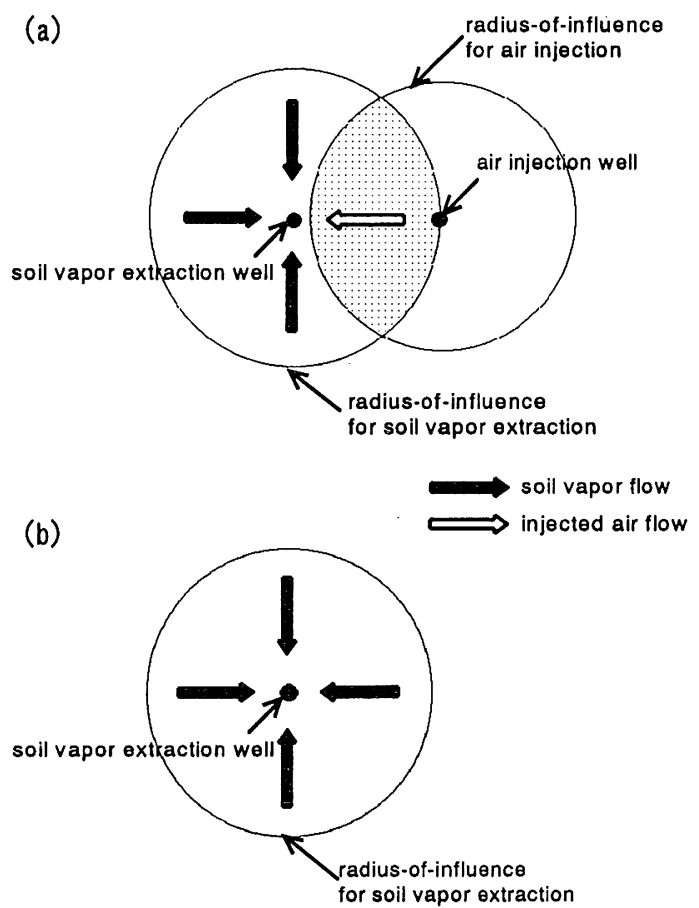

Fig. 7 Schematic illustration of gas flow in unsaturated zone. 


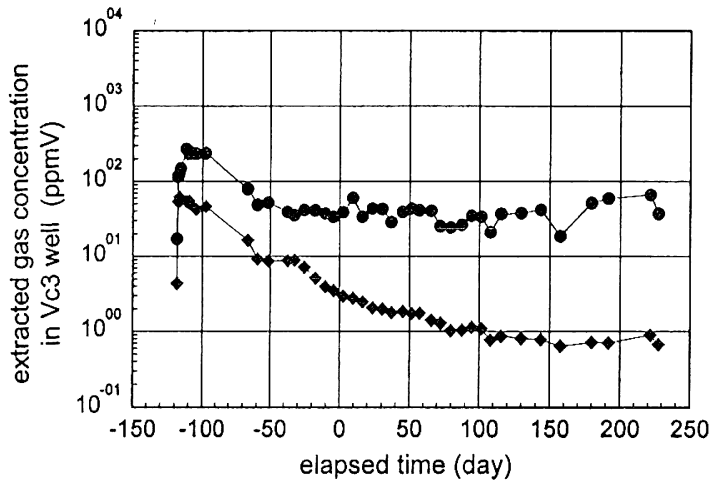

Fig. 8 Time varied change of gas concentrations in extraction well: Vc3.

$:$ toluene, $:$ tetrachloroethylene.

計算にテトラクロロエチレンを用いたのは、抽出 ガス、土壤ガスおよび地下水中濃度の変化に空気 注入の影響が顕著に見られるためである。

仮定：1）注入空気の流れに異方性はなく、注入 井を中心に同心円状に拡がる。

2) 空気は 3 本の注入井から同時に 40L min ${ }^{-1}$ の流量で注入されている。

3 ) 抽出の影響半径は $6 \mathrm{~m}$ である。

4 ）注入空気の影響半径は $5.5 \mathrm{~m}$ である。

5 ）対象領域内の土壤ガス濃度、地下水中 濃度は一定である。

空気注入は 3 本の井戸のうち 1 本ずつ順番に $120 \mathrm{Lmin}^{-1}$ の流量で 1 時間動かし、その他の 2 本 は休止させる間欠運転で行っている。1 本の注入 井で考えると、注入された空気の影響で注入井か ら抽出井に向かった方向の土壤ガス圧力が上昇 し、抽出の影響範囲が変化する (江種ほか、1998)。 すなわち、抽出の影響範囲に異方性が生じている。 しかし、1 時間毎に順次井戸を変えながら空気注 入を行っているため、長期的に考えると 3 本の井 戸を同時に動かす運転と同じ効果になると予想さ れる。この場合、単位時間当たりの注入量 $120 \mathrm{Lmin}^{-1}$ が 3 本の注入井に均等に割り当てられ ると考えられるので、1本の注入井からは $40 \mathrm{Lmin}^{-1}$ の流量で空気が注入されているとする。 さらに、Vc1は周囲を 3 本の注入井に囲まれてい るため、抽出の影響は次第に注入井の外側には及
ばなくなる。そこで、抽出の影響半径は抽出井か ら注入井までの距離 $6 \mathrm{~m}$ とする。注入の影響半径 は注入空気による濃度の低下が見られた観測井ま での距離 $5.5 \mathrm{~m}$ とする。ここで、Vc1から回収され る注入空気は、注入と抽出の影響範囲が重なる領 域の不飽和带に出てきたものである (Fig.7 (a) 参 照)。土壤ガス濃度には、 $\mathrm{V} c 1$ の影響範囲内の平 均土壤ガス濃度に相当する抽出ガス濃度、注入停 止期間中の35日後と70日後の值を用いる (Fig.6中 抽出井 Vc1のシンボル口)。一方、抽出ガス濃度 には、各時点で空気注入を停止する直前 (Fig.6の シンボル國の直前、30日後と65日後)の值を用い る。以上の仮定をもとに、注入空気中のテトラク ロロエチレン濃度を次式により計算すると、それ ぞれ5.06ppmV および1.43ppmVになった。得られ た值は空気注入期間中の Vc3の抽出ガス濃度 (35 日後で1.80ppmV、70日後で1.20ppmV)より高い が、Vc1より(35日後で6.01ppmV、70日後で4.93 $\mathrm{ppmV}$ ) も低く、これは前節で推測した注入空気中 に揮発したガス濃度の範囲であることから、おお よそ妥当な值と思われる。

$C_{a}=\left[C_{v} \times 120-C_{g} \times(120-Q)\right] / Q$

ここに、 $\mathrm{C}_{\mathrm{a}}$ : 注入空気中に含まれる濃度 $[\mathrm{ppmV}]$ 、 $\mathrm{C}_{\mathrm{v}}$ : 抽出ガス濃度 $(=5.63 \mathrm{ppmV}: 30$ 日後、3.53ppmV: 65 日後)、 $\mathrm{C}_{\mathrm{g}}$ : 土壤ガス濃度 $(=6.01 \mathrm{ppmV}: 35$ 日後、 4.93ppmV:70日後)、 $\mathrm{Q}$ ：抽出の影響範囲内に出て くる注入空気総量 $\left(=48 \mathrm{Lmin}^{-1}\right)$ である。注入空気 総量 Q は、抽出の影響範囲内に出てくる注入井 1 本あたりの注入空気量 (計算で使用する注入空 気量 $40 \mathrm{Lmin}^{-1} \times$ 抽出と注入の影響範囲の重なった 領域の面積 / 注入の影響範囲全域の面積 :Fig.6 参照)を 3 倍して求めている。

一方、この近辺に扔ける地下水中のテトラクロ ロエチレン濃度の平均值は、 $\mathrm{V} c 1$ 影響範囲内に 設置された地下水観測井の中で注入空気の影響が 見られる井戸(Fig.3中 Md2-1 3および Fig2中 Md7-1〜3のシンボル国)を用いて算定すると、35 日後が $0.155 \mathrm{mgL}^{-1} 、 70$ 日後が $0.077 \mathrm{mgL}^{-1}$ であった。 この值とヘンリー定数 0.3641 (例えば、西村・水 上、1995)から気液平衡ガス濃度 $\left(\mathrm{mgL}^{-1}\right)$ を計算 し、 $\mathrm{ppmV}$ の単位に換算すると8.15ppmV および4.06 
$\mathrm{ppmV}$ となった。これらの值は注入空気に揮発し たガス濃度の推定值よりも高い。すなわち、現地 における地下水と注入空気の界面における物質輸 送過程 (揮発過程) は平衡には達していないと思わ れる。江種ら (1994)が行った室内カラム実験によ ると、含水率が気相率よりも大きい不飽和帯にお いて、液相中のテトラクロロエチレン濃度が20.0

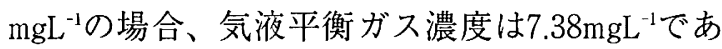

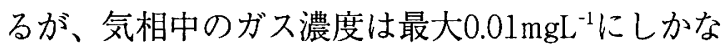
らないことが確認されている。このことは、気液 界面の物質輸送過程は平衡状態になりにくい、仮 に平衡になるとしても非常に時間がかかることを 示している。したがって、カラム実験に扮ける(土 壤ガス濃度 / 気液平衡ガス濃度)の值 (約700分の 1)を参考にすると、実スケール野外実験中の (注 入空気に揮発したガス濃度/気液平衡ガス濃度） の值も同様に小さいと予想できる。しかし、実際 には35日後の注入空気に揮発したガスの濃度が気 液平衡ガス濃度の 5 分の 3 程度になっており、注 入空気中のテトラクロロエチレンはすべてが地下 水中からの揮発によるものではないと思われる。 地下水中からの揮発以外の原因を考えると、残り は原液からの揮発である。すなわち、（注入空気 に揮発したガス濃度/気液平衡ガス濃度)の值 は、その值が小さい場合には地下水中に溶解して いる物質の溶解だけが生じ、大きい場合には地下 水中に存在している原液からの揮発も生じている ことを示していると推察される。

以上のように、抽出ガス濃度、土壤ガス濃度、 そして地下水中濃度を用いて注入空気中に含まれ ているテトラクロロエチレン濃度を算定し、気液 平衡ガス濃度と比較することで、抽出井 V $\mathrm{c} 1$ の影 響範囲内の地下水中に原液が存在している可能性 が認められた。ただし、70日後には注入空気に揮 発したガスの濃度が気液平衡ガス濃度の 3 分の 1 程度にまで小さくなっていることから、時間が経 過するにつれて地下水中に注入された空気への揮 発によって原液が大きく減少し、污染された地下 環境が回復しているものと思われる。

\section{5. おわりに}

本研究では、揮発性物質が地下水中に注入され
た空気に揮発することで水質が回復していく様子 を調べるために、長期間の実スケール野外実験を 実施した。その結果、空気注入を断続的に行う間 欠運転によって注入空気の影響範囲がほぼ実験対 象領域全域に達してることが明らかになった。特 に地下水面下深い場所における影響範囲の拡がり が大きい。また、抽出ガスと土壤ガス濃度、そし て地下水中濃度から間接的ではあるが注入空気に 揮発したガス濃度が算定でき、その妥当性も確め られた。さらに、(注入空気に揮発したガス濃度 / 気液平衡ガス濃度)の值の時間変化から、地下 水中に溶解している物質と共に地下水中に存在し ている原液も注入空気の影響で減少しつつある状 況が推察できた。ただし、物質毎の濃度低下の違 いなど、実スケール野外実験だけでは解明できな い詳細な現象もあり、今後は室内実験や数值シ ミュレーションを行い、注入空気の流れがどの程 度地下水の攪拌に影響を与えるか、地下水中の濃 度や物質毎の揮発性の違いなどが濃度変化にどの ような影響を与えるかなどを検討していく予定で ある。

\section{参考文献}

江種伸之・神野健二・鷲見栄一(1994)：ガス拡散を考 慮した有機塩素化合物の不飽和一飽和領域における 輸送特性解析、土木学会論文集、503( II -29)、 167-176.

江種伸之・平田健正・福浦清 - 松下孝(1998)：地下水 中に注入された空気の移動特性掞よび污染物質の濃 度変化について、水工学論文集、42、349-354.

笠水上光博 - 山内仁 - 前川統一郎 - 西田道夫 · 岡田滋 (1995)：エアースパージング・揚水システムの効 果、地下水・土壤污染とその防止対策に関する研究 集会第 4 回講演集、339-342.

笠水上光博・山内仁・岡田滋(1997)：エアースパージ ング・揚水システムの効果その 2 、地下水・土塞污 染とその防止対策に関する研究集会第 5 回講演集、 373-378.

長藤哲夫・今村聡・日下部治・平田健正 (1998)：揮発 性有機塩素化合物の土壤ガス吸引法における浄化影 響要因に関する研究、土木学会論文集、594(VII-7)、 35-44. 
西村実・水上春樹 (1995)：工業用洗浄剤に污染された 土壌や地下水の浄化、洗浄設計、Autumn、11-19.

平田健正 - 江種伸之 - 中杉修身 - 石坂信也(1996)：土 壤ガス吸引と地下水揚水を併用した地下環境污染の 修復、環境工学研究論文集、33、47-55.

Ji, W., A. Dahmani, D.P. Ahlfeld, J.D. Lin, E, Hill III (1993) : Laboratory study of air sparging: air flow visualization, Groundwater Monitoring and Remedia. tion, Fall 1993, 115-126.

Unger, A.J.A, E.A. Sudicky and P.A. Forsyth(1995a) : Efficiency of air sparging for remediation of heterogeneous formations contaminated by dense non aqueous phase liquids, Gronndwater Quality: Remediation and Protection, IAHS Publisher, 225, 449-456.

Unger, A.J.A, E.A. Sudicky and P.A. Forsyth(1995b) : Mechanisms controlling vacuum extraction coupled with air sparging for remediation of heterogeneous formations contaminated by dense nonaqueous phase liquids, Water Resources Research, 31 (8), 1913-1925. Lundegard, P.D. and D. LaBrecue (1995) : Air sparging in a sandy aquifer (Florence, Oregon, U.S.A.): Actual and apparent radius of influence, Joumal of Contaminant Hydrology, 19, 1-27.

（受付：1998年 7 月 1 日、受理：1998年10月 6 日） 